\title{
Preclinical research and development of a herbal antipyretic drug based on leaves of Ceiba pentandra (Malvaceae)
}

\section{Awa Nounaferi Gnieneferetien Silue*, Lenoir Thierry Ayoman Djadji, Landry S. Kouakou, Gisele N'doua Siransy-Kouakou}

\begin{abstract}
Laboratory of Pharmacology, Training and Research Unit of Pharmaceutical and Biological Sciences, Felix Houphouet-Boigny University, Abidjan, Côte d'Ivoire, West Africa
\end{abstract}

Received: 12 October 2020

Accepted: 17 November 2020

\author{
*Correspondence: \\ Dr. Awa Nounaféri Gniènèfèrètien Silué, \\ Email: silue.gna@gmail.com
}

Copyright: ( $)$ the author(s), publisher and licensee Medip Academy. This is an open-access article distributed under the terms of the Creative Commons Attribution Non-Commercial License, which permits unrestricted non-commercial use, distribution, and reproduction in any medium, provided the original work is properly cited.

\begin{abstract}
Background: Faced with the limits of synthetic antipyretic substances, in particular their involvement in the occurrence of numerous and often serious adverse effects; the challenge is in search of new antipyretics especially from the African traditional pharmacopoeia. The objective of this study was to evaluate the antipyretic activity of an aqueous extract and a formulation of Ceiba pentandra, with a view to designing an herbal antipyretic drug.

Methods: Trials of formulation of an antipyretic syrup with leaves extract of Ceiba pentandra were carried out. The antipyretic activity was investigated by the bewer's yeast induced pyrexia. Physicochemical and microbiological stability tests were carried out on the syrup.

Results: It was found with the extract an antipyretic activity at doses of $125 \mathrm{mg} / \mathrm{kg}$ and $150 \mathrm{mg} / \mathrm{kg}$. The effect was greater for the $125 \mathrm{mg} / \mathrm{kg}$ dose with inhibition percentages ranging from $27.58 \%$ to $71.25 \%$. This antipyretic activity was early (from 30 minutes) and was preserved during the four hours of the experiment. The syrup dosed at 125 $\mathrm{mg} / \mathrm{kg}$ gave an activity similar to that of the extract by significantly reducing the hyperthermia in the rats. Regarding the stability tests, the syrup remained stable both physico-chemically and microbiologically throughout the study period (28 days) both when exposed to low temperature $\left(5^{\circ} \pm 3^{\circ} \mathrm{C}\right)$ and at high temperature $\left(40^{\circ} \pm 2^{\circ} \mathrm{C}\right)$.

Conclusions: Ceiba pentandra leaves have antipyretic activity and could be used for the development of an herbal antipyretic drug.
\end{abstract}

Keywords: Ceiba pentandra, Antipyretic, Herbal drug

\section{INTRODUCTION}

Fever is an increase in body temperature above $38^{\circ} \mathrm{C} .{ }^{1}$ It classically refers to a body temperature $\geq 38^{\circ} \mathrm{C}$ in the morning $\left(38.3^{\circ} \mathrm{C}\right.$ in the evening). ${ }^{1}$ The main symptom of infectious pathology, it is generally a reaction of the body in the presence of a foreign body (toxic substances, bacterial infections, etc.) that affect temperature regulation. $^{2}$ The mechanism of fever occurrence is closely related to the concentration of prostaglandin PGE. ${ }^{2}$ Thus, fever occurs when the concentration of PGE increases in the hypothalamus which is the center of thermoregulation disturbing the balance between loss and production of heat. ${ }^{2,3}$ Rapid treatment of this should be done because it can be the cause of serious complications (dehydration, convulsions, etc.) in infants and the elderly. ${ }^{4}$

Drug management of fever is essentially based on the use of synthetic substances endowed with antipyretic activities, in particular paracetamol, aspirin and certain anti-inflammatory drugs. Although widely prescribed, these substances are responsible for many often-serious side effects. Paracetamol, the most widely used analgesic-antipyretic drug in the world, is the leading 
cause of fulminant hepatitis in the United States and Europe. $^{5}$

Therefore, it would be desirable to direct research towards the development of phytomedicines that are just as effective and free from adverse effects.

Ceiba pentandra or silk cotton tree, an imposing tree from the forests of tropical regions is a medicinal plant widely known for its uses in traditional medicine. ${ }^{6,7}$ Also, the leaves are prized for their edible character and consumed as a leaf vegetable in West Africa, with an acute toxicity greater than $5000 \mathrm{mg} / \mathrm{kg} .{ }^{8-11}$

Previous work has shown the antipyretic activity of the ethanolic extract of the leaves of Ceiba pentandra. ${ }^{12}$ However, scientific data on the antipyretic activity of the aqueous extract is limited. The present study therefore aimed to evaluate the antipyretic activity of an aqueous decoction and of a formulation of Ceiba pentandra for the development of a herbal drug.

\section{METHODS}

\section{Plant collection and identification}

Fresh leaves of Ceiba pentandra were collected from Nabélékaha in the department of Komorodougo (North of Côte d'Ivoire). The plant was identified by the Centre National de Floristique (CNF) of the botany department of the Félix Houphouët-Boigny University of Abidjan.

\section{Extraction of plant material}

Two hundred grams (200g) of fresh leaves were brought to a boil for thirty (30) minutes in two (2) liters of distilled water. After filtration, the decoction was evaporated dry in an oven at a temperature of $50^{\circ} \mathrm{C}$ for 72 hours. The anhydrous material obtained was collected by scraping. After crushing, the brown dry extract obtained was stored at $4^{\circ} \mathrm{C}$ in the refrigerator. This was used for phytochemical and pharmacological tests.

\section{Experimental animals}

All experiments performed on the laboratory animals in this study followed the standard operating procedures. A total of forty (40) wistar rats (Rattus norgevicus) weighing between 100-170 g of both sexes were used for the study of antipyretic activity. These animals were provided by the animal facility of the Pharmacology Laboratory of the Training and Research Unit of Pharmaceutical and Biological Sciences of Félix Houphouët-Boigny University in Abidjan. The rats were acclimated under standard conditions of temperature $24^{\circ} \mathrm{C} \pm 1^{\circ} \mathrm{C}$ with $75 \%$ humidity and light (approximately $12 / 24$ light-dark cycle). All the animals were fasted for 24 hours but allowed water ad libitum were used for the experiment.

\section{Phytochemical screening}

In order to identify the presence of different classes of secondary metabolites in the plant material, a qualitative phytochemical screening was carried out on the dry extract following standard procedures and tests. ${ }^{13}$

\section{Antipyretic activity}

The antipyretic activity of leaves of Ceiba pentandra was evaluated by using the brewer's yeast-induced pyrexia method in rat. After taking the basal temperatures, hyperthermia was induced by the subcutaneous administration in the dorso-lumbar region of a $20 \%$ saline suspension of beer yeast in rats at $10 \mathrm{ml} / \mathrm{kg}$ body weight. ${ }^{14}$ The animals were then fasted, after sixteen (16) hours the rectal temperature was taken again in each rat, and six (6) groups of rats were formed with rats with a temperature increase greater than or equal to $0,5^{\circ} \mathrm{C}$. The groups have been made homogeneous in terms of hyperthermia. The individual batches were orally administered either $0.09 \% \mathrm{NaCl}$ solution, or extract from Ceiba pentandra leaves $(100 ; 125$ and $150 \mathrm{mg} / \mathrm{kg}$ ), or syrup based on extracts from Ceiba pentandra leaves $(125 \mathrm{mg} / \mathrm{kg})$, or the reference substance paracetamol (100 $\mathrm{mg} / \mathrm{kg}$ ). Thirty minutes after the administration of the substances, the temperature $\left(\mathrm{T}^{\circ} \mathrm{n}\right)$ was taken using a digital thermometer TMP $812 \mathrm{RS}^{\mathrm{TM}}$. Then the temperature was measured every hour for four hours.

Fever inhibition percentages were calculated in relation to control $(\mathrm{NaCl} 0.9 \%)$ according to the following formula:

$\%$ inhibition $=\left[\left(\mathrm{T}^{\circ} \mathrm{n}-\mathrm{T}^{\circ}-16\right)\right.$ control $-\left(\mathrm{T}^{\circ} \mathrm{n}-\mathrm{T}^{\circ}-16\right)$ treated] $/\left(\mathrm{T}^{\circ} \mathrm{n}-\mathrm{T}^{\circ}-16\right)$ control $\times 100$

Where, $\mathrm{T}^{\circ} \mathrm{n}=$ temperature measured after administration of antipyretic treatment, $\mathrm{T}^{\circ}-16=$ basal temperature

\section{Procedure for preparation of syrup}

To prepare liquid oral form of the extract, the following steps were taken:

\section{Preparation of simple syrup}

Distilled water was heated to the water bath at a temperature of $60^{\circ} \pm 2^{\circ} \mathrm{C}$. $1650 \mathrm{~g}$ of sucrose was gradually added to the water by stirring with a glass rod until a homogeneous whole was obtained (complete dissolution of the sugar). The preparation was then filtered using a 50 $\mu \mathrm{m}$ diameter sieve and the simple syrup was used as vehicle.

\section{Preparation of Ceiba pentandra leaf extract syrup}

One hundred milliliters of $125 \mathrm{mg} / 5 \mathrm{ml}$ of drug syrup was prepared by adding to 2.5 grams of dried extracts of 
Ceiba pentandra leaves a sufficient quantity of simple syrup until saturation.

\section{Stability testing of Ceiba pentandra leaf extract syrup}

The physical and microbiological stability of the formulation was evaluated. Three storage conditions were tested: room temperature $\left(25 \pm 2^{\circ} \mathrm{C}\right)$, oven $\left(40 \pm 2^{\circ} \mathrm{C}\right)$ and refrigerator $\left(5 \pm 3^{\circ} \mathrm{C}\right) .{ }^{15}$

At the physicochemical level, the constancy of organoleptic characteristics (colour, appearance), density, viscosity and $\mathrm{pH}$ were evaluated.

Total viable aerobic count, moulds and yeasts count, and the search for the following germs: Escherichia coli, Salmonella, Staphylococcus aureus, Pseudomonas aeruginosa were carried out according to the procedures listed in the 8th edition of the European Pharmacopoeia.

Measurements were taken on Day 0, Day 1, Day 2, Day 7, Day 14, Day 21 and Day 28 for each storage temperature for physical parameters. For microbiology y, the assessment was conducted on Day 0 and Day 28.

\section{Ethical approval}

The experimental procedures were conducted after the approval of the Ethical Guidelines of the University (Côte d'Ivoire) Committee on Animal Resources. All these procedures used, were in strict accordance with the guidelines for Care and Use of Laboratory Animals and the statements of the European Union regarding the handling of experimental animals (86/609/EEC).

\section{Statistical analysis}

The analysis of the test results was carried out on the basis of statistical processing using Graph Prism software version 7.0. One-way ANOVA followed by Dunnett's test was used as statistical processing. The values of $\mathrm{p}<0.05$ were considered as statistically significant.

\section{RESULTS}

\section{Phytochemical screening}

The phytochemical screening of the dry extract of leaves of Ceiba pentandra showed presence of sterols, phenolic compounds, quinones, tannins, flavonoids and saponins (Table 1).

\section{Antipyretic activity}

Treatment of the animals with the aqueous extract of Ceiba pentandra, at the dose of $125 \mathrm{mg} / \mathrm{kg}$ and 150 $\mathrm{mg} / \mathrm{kg}$ body weight, significantly $(\mathrm{p}<0.05)$ decreased the rectal temperature of the test rats. The antipyretic effect started from the first 30 minutes for all the extract doses and the standard drug. This effect was maintained for the 4 hours of experimentation and was increasing with plant extracts unlike the reference drug. The syrup of dried extracts of Ceiba pentandra leaves showed a similar activity to that of not-formulated extracts during the two hours following administration of the different substances (Table 2).

Table 1: Chemical composition of the aqueous extracts of Ceiba pentandra leaves.

\begin{tabular}{|ll|}
\hline Secondary metabolite & Leaves extract \\
\hline Sterols & + \\
\hline Polyphenols & + \\
\hline Quinones & + \\
\hline Catechetical tannins & + \\
\hline Gallic tannins & - \\
\hline Flavonoids & + \\
\hline Alkaloids & - \\
\hline Saponins & Foam index $<100$ \\
\hline
\end{tabular}

Table 2: The effect of aqueous leaf extract and syrup of Ceiba pentandra on yeast-induced pyrexia in rat.

\begin{tabular}{|lllllllll|}
$\begin{array}{l}\text { Drug } \\
\text { dose } \\
\text { (mg/kg) }\end{array}$ & T-16 & T0 & T0,5 & T1 & T2 & T3 & T4 \\
\hline $\begin{array}{l}\text { NaCl } \\
(\mathbf{0 . 9 \%})\end{array}$ & $36.45 \pm 0.32$ & $37.38 \pm 0.32$ & $37.42 \pm 0.22$ & $37.95 \pm 0.20$ & $38.03 \pm 0.28$ & $37.58 \pm 0.34$ & $37.78 \pm 0.28$ \\
\hline Para 100 & $37.18 \pm 0.42$ & $38.22 \pm 0.12$ & $\begin{array}{l}37.23 \pm 0.47 * \\
(94.83 \%)\end{array}$ & $\begin{array}{l}37.35 \pm 0.33 * \\
(88.88 \%)\end{array}$ & $\begin{array}{l}37.82 \pm 0.24 \\
(60 \%)\end{array}$ & $\begin{array}{l}38.4 \pm 0.41 \\
(33.82 \%)\end{array}$ & $\begin{array}{l}38.4 \pm 0.61 \\
(37.5 \%)\end{array}$ \\
\hline CPD 100 & $36.57 \pm 0.21$ & $37.4 \pm 0.07$ & $\begin{array}{l}37.25 \pm 0.17 \\
(29.31 \%)\end{array}$ & $\begin{array}{l}37.85 \pm 0.22 \\
(14.44 \%)\end{array}$ & $\begin{array}{l}38.12 \pm 0.15 \\
(2.11 \%)\end{array}$ & $\begin{array}{l}37.6 \pm 0.20 \\
(8.82 \%)\end{array}$ & $\begin{array}{l}37.73 \pm 0.23 \\
(12.5 \%)\end{array}$ \\
\hline CPD 125 & $36.23 \pm 0.34$ & $37.33 \pm 0.33$ & $\begin{array}{l}36.93 \pm 0.23 \\
(27.58 \%)\end{array}$ & $\begin{array}{l}37.05 \pm 0.78 * \\
(45.55 \%)\end{array}$ & $\begin{array}{l}36.95 \pm 0.38 * \\
(54.73 \%)\end{array}$ & $\begin{array}{l}36.73 \pm 0.6 * \\
(55.88 \%)\end{array}$ & $\begin{array}{l}36.62 \pm 0.25 * \\
(71.25 \%)\end{array}$ \\
\hline CPD 150 & $36.15 \pm 0.29$ & $37.08 \pm 0.1$ & $\begin{array}{l}37.05 \pm 0.1 \\
(6.90 \%)\end{array}$ & $\begin{array}{l}37.22 \pm 0.3 * \\
(28.89 \%)\end{array}$ & $\begin{array}{l}37.48 \pm 0.28 * \\
(15.78 \%)\end{array}$ & $\begin{array}{l}37 \pm 0.26 \\
(25 \%)\end{array}$ & $\begin{array}{l}36.78 \pm 0.36 * \\
(52.5 \%)\end{array}$ \\
\hline Syrup 125 & $36.18 \pm 0.42$ & $37.02 \pm 0.38$ & $\begin{array}{l}36.77 \pm 0.30 * \\
(39.65 \%)\end{array}$ & $\begin{array}{l}36.85 \pm 0.28 * \\
(55.55 \%)\end{array}$ & $\begin{array}{l}36.88 \pm 0.18 * \\
(55.79 \%)\end{array}$ & $\begin{array}{l}37.1 \pm 0.33 \\
(19.11 \%)\end{array}$ & $\begin{array}{l}37.18 \pm 0.41 \\
(25 \%)\end{array}$ \\
\hline
\end{tabular}

Results are mean \pm SEM; $(n=6)$; each value in parenthesis indicates the percentage inhibition, *significantly at $p<0.05$ when compared to control, $\mathrm{CPD}=$ aqueous extract of Ceiba pentandra leaves. Para $=$ paracetamol. 
Table 3: The Physico-chemical stability of the syrup.

\begin{tabular}{|c|c|c|c|c|c|c|c|}
\hline \multirow[t]{2}{*}{ Syrup } & \multirow{2}{*}{$\begin{array}{l}\text { Time } \\
\text { (Day) }\end{array}$} & \multirow{2}{*}{$\mathbf{T}\left({ }^{\circ} \mathbf{C}\right)$} & \multicolumn{2}{|c|}{ Organoleptic characters } & \multirow{2}{*}{ pH } & \multirow{2}{*}{ Density } & \multirow{2}{*}{$\begin{array}{l}\text { Viscosity } \\
\text { (Pa.s) }\end{array}$} \\
\hline & & & Color & Limpidity & & & \\
\hline CP1A & \multirow{3}{*}{$\mathrm{J} 0$} & $5 \pm 3$ & Brown & Limpid & 6.20 & 1.302 & 222.33 \\
\hline CP1B & & $25 \pm 2$ & Brown & Limpid & 6.21 & 1.302 & 222.66 \\
\hline CP1C & & $40 \pm 2$ & Brown & Limpid & 6.21 & 1.302 & 222.66 \\
\hline CP2A & \multirow{3}{*}{$\mathrm{J} 1$} & $5 \pm 3$ & Brown & Limpid & 6.18 & 1.302 & 224.33 \\
\hline CP2B & & $25 \pm 2$ & Brown & Limpid & 6.20 & 1.304 & 221.33 \\
\hline CP2C & & $40 \pm 2$ & Brown & Limpid & 6.21 & 1.303 & 220.66 \\
\hline CP3A & \multirow{3}{*}{$\mathrm{J} 2$} & $5 \pm 3$ & Brown & Limpid & 6.15 & 1.301 & 220.33 \\
\hline CP3B & & $25 \pm 2$ & Brown & Limpid & 6.03 & 1.304 & 219.00 \\
\hline CP3C & & $40 \pm 2$ & Brown & Limpid & 6.19 & 1.303 & 217.33 \\
\hline CP4A & \multirow{3}{*}{$\mathrm{J} 7$} & $5 \pm 3$ & Brown & Limpid & 6.12 & 1.301 & 222.33 \\
\hline CP4B & & $25 \pm 2$ & Brown & Limpid & 6.03 & 1.304 & 217.00 \\
\hline CP4C & & $40 \pm 2$ & Brown & Limpid & 6.20 & 1.303 & 215.66 \\
\hline CP5A & \multirow{3}{*}{$\mathrm{J} 14$} & $5 \pm 3$ & Brown & Limpid & 6.10 & 1.302 & 222.33 \\
\hline CP5B & & $25 \pm 2$ & Brown & Limpid & 5.94 & 1.304 & 216.33 \\
\hline CP5C & & $40 \pm 2$ & Brown & Limpid & 6.18 & 1.303 & 211.00 \\
\hline CP6A & \multirow{3}{*}{$\mathrm{J} 21$} & $5 \pm 3$ & Brown & Limpid & 6.13 & 1.302 & 221.33 \\
\hline СР6В & & $25 \pm 2$ & Brown & Limpid & 5.86 & 1.305 & 217.00 \\
\hline СР6C & & $40 \pm 2$ & Brown & Limpid & 6.20 & 1.303 & 209.33 \\
\hline CP7A & \multirow{3}{*}{$\mathrm{J} 28$} & $5 \pm 3$ & Brown & Limpid & 6.15 & 1.302 & 223.33 \\
\hline CP7B & & $25 \pm 2$ & Brown & Limpid & 5.87 & 1.305 & 216.00 \\
\hline CP7C & & $40 \pm 2$ & Brown & Limpid & 6.22 & 1.303 & 207.66 \\
\hline
\end{tabular}

T: temperature; CPD1A: Syrup stored at room temperature $\left(25 \pm 3^{\circ} \mathrm{C}\right)$; CPD1B: Syrup stored in an oven $\left(40 \pm 2^{\circ} \mathrm{C}\right)$; CPD1C: Syrup stored in the refrigerator $\left(5 \pm 3^{\circ} \mathrm{C}\right)$.

Table 4: Microbiological control of Ceiba pentandra leaf extract syrup.

\begin{tabular}{|c|c|c|c|}
\hline \multirow{2}{*}{ Microbiological examination } & \multicolumn{2}{|l|}{ Results } & \multirow{2}{*}{$\begin{array}{l}\text { European pharmacopoeia } \\
\text { standards 8th edition }\end{array}$} \\
\hline & Day 0 & Day 28 & \\
\hline \multirow{3}{*}{ Total viable aerobic count } & CPD1A $:<10$ & CPD1A $: 10^{4}$ & \multirow{3}{*}{$<10^{4} \mathrm{UFC} / \mathrm{ml}$} \\
\hline & CPD1B $:<10$ & CPD1B $:<10$ & \\
\hline & CPD1C $:<10$ & CPD1C :60 & \\
\hline \multirow{3}{*}{ Yeast and mould } & CPD1A $:<10$ & CPD1A :34.10 3 & \multirow{3}{*}{$<10^{2} \mathrm{UFC} / \mathrm{ml}$} \\
\hline & CPD1B $:<10$ & CPD1B : <10 & \\
\hline & CPD1C $:<10$ & CPD1C $: 10$ & \\
\hline \multirow{3}{*}{$\begin{array}{l}\text { Bile-tolerant gram-negative } \\
\text { bacteria }\end{array}$} & CPD1A $:<10$ & CPD1A : $<10$ & \multirow{3}{*}{$<10^{2} \mathrm{UFC} / \mathrm{ml}$} \\
\hline & CPD1B $:<10$ & CPD1B : $<10$ & \\
\hline & CPD1C $:<10$ & CPD1C $:<10$ & \\
\hline Salmonella & Absence & Absence & Absence \\
\hline Escherichia Coli & Absence & Absence & Absence \\
\hline Pseudomonas aeroginosa & Absence & Absence & Absence \\
\hline Staphylococcus aureus & Absence & Absence & Absence \\
\hline
\end{tabular}

T: temperature; CPD1A: Syrup stored at room temperature $\left(25 \pm 3^{\circ} \mathrm{C}\right)$; CPD1B: Syrup stored in an oven $\left(40 \pm 2^{\circ} \mathrm{C}\right)$; CPD1C: Syrup stored in the refrigerator $\left(5 \pm 3^{\circ} \mathrm{C}\right)$.

\section{Stability testing of Ceiba pentandra leaf extract syrup}

The syrup of dried extracts of leaves of Ceiba pentandra had the following characteristics: a good appearance without deposit, a sweet taste, a color of caramel (brown). The density was 1.30 and the $\mathrm{pH}$ was 6 .

After 28 days, the syrup remained clear, the organoleptic parameters did not change; density and viscosity have not been changed at different storage temperatures. A slight decrease in $\mathrm{pH}$ was observed in syrup stored at room temperature, as opposed to those in the refrigerator and oven (Table 3 ).

The microbiological quality according to the requirements of the European Pharmacopoeia did not reveal the presence of any microorganisms in the syrup beyond the limits set. Also, during 28 days of storage there was no mould formation in the syrup stored in the refrigerator and oven (Table 4). 


\section{DISCUSSION}

The limits of synthetic antipyretic substances, in particular their involvement in the occurrence of harmful effects on the organism, open other avenues for the search for new antipyretics from the traditional pharmacopoeia. The objective of this work was to evaluate the antipyretic activity of an aqueous extract and a formulation of Ceiba pentandra extract, with a view to designing an antipyretic herbal drug.

The antipyretic effect of the leaves of Ceiba pentandra was studied by Brewer's yeast-induced pyrexia in rat. The brewer's yeast consists of lipopolysaccharides of the Saccharomyces cerevisiae cell wall. Its administration induces hyperthermia by releasing of cytokines, in particular interleukins (IL1, IL6). When they reach the blood vessels, they stimulate the synthesis of prostaglandins E2 around the hypothalamic center. ${ }^{16,17}$ The aqueous decoction of the leaves of Ceiba pentandra reduced the hyperthermia induced by the brewer's yeast. Of the three doses tested, the $125 \mathrm{mg} / \mathrm{kg}$ dose resulted in significant antipyretic activity. Indeed, the dry extract dosed at $125 \mathrm{mg} / \mathrm{kg}$ shows an early febrifuge effect, which is maintained over time with percentages of inhibitions that increase with time. The most active dose was lower than in previous studies of an ethanolic extract from leaves of Ceiba pentandra. Authors had found an effective dose of $189 \mathrm{mg} / \mathrm{kg}$. Also, the antipyretic effect was not dose-dependent as demonstrated by the same authors 12. This observed effect could be due to the presence of bioactive compounds which justified the phytochemical screening.

Phytochemical screening revealed the presence of sterols, flavonoids, tannins and polyphenols, saponosides and quinones in Ceiba pentandra leaves dry extract. The presence of some of these chemicals in the leaves may be responsible for the pharmacological properties observed. Indeed, the antipyretic activity could be explained by the presence in the aqueous extract of Ceiba pentandra of flavonoids, polyphenols, tannins and saponins which have the property of inhibiting the synthesis of proinflammatory cytokines (IL-1b, IL-6, TNF $\alpha$ and INF gamma). ${ }^{18,19}$ In addition to these antipyretic properties the toxicity studies showed that the plant could be considered non-toxic. The LD50 greater than $5000 \mathrm{mg} / \mathrm{kg}$ and the edible character of the leaves of Ceiba pentandra would guarantee the security of use of the plant within a finished drug formulation. ${ }^{8-11}$

After the aqueous extracts have been put in galenic form, the syrup obtained has the following characteristics:

The $\mathrm{pH}$ of the syrup was 6.21 to $25 \pm 2^{\circ} \mathrm{C}$. The results are consistent with those of two studies in which syrups based on plant leaf extracts were formulated. John et al had obtained a pH of 6.61 and Swain et al had found a $\mathrm{pH} 4.5$. The $\mathrm{pH}$ of the stomach being acidic: 1.5 at night and 5 at the beginning of digestion, Ceiba pentandra leaf extract syrup is therefore suitable for absorption at this level since it is limited to acidic medicines. ${ }^{20-22}$ The density of the syrup of dried extracts was 1.30 ; this is close to the density of the simple syrup which is $1.32 .^{23}$

In terms of conservation of the antipyretic effect, the syrup showed an early antipyretic activity superimposed on that of the raw extract during the first two hours of the experiment. However, a decrease in activity was noted starting at the third hour compared to the aqueous extract. This could be due to an interaction between active substances and sugar syrup within the formulation.

The organoleptic characteristics of the syrup remained unchanged in the stability tests at the three storage temperatures. In fact, no change in colour or appearance was noted. Also, no suspended particles were observed in the preparation: the syrup remained clear during the 28day storage period. The density with an average value of 1.30 did not change. Regarding $\mathrm{pH}$, a non-significant decrease was noted in syrups stored at room temperature from the 14th day of storage.

Viscosity also remained constant. In addition to physicochemical stability, microbiological stability is another problem related to the quality of liquid oral forms. This microbiological quality is particularly important since the presence of a micro-organism in the formulation may reduce the effectiveness of the active ingredient or be dangerous for at-risk patients such as infants and young children. Microbial enumeration and microbial research tests, carried out in accordance with the recommendations of the European Pharmacopoeia, demonstrated the microbiological stability of the preparations stored in the refrigerator and oven after manufacture over a period of 28 days.

However, total aerobic sprout counts were positive for syrup stored at room temperature. The search for microorganisms came back positive for yeast and mould only, which could explain the lower $\mathrm{pH}$ of syrups kept at this temperature. Therefore, the formulation should be improved by adding a preservative to allow storage at room temperature.

\section{CONCLUSION}

This study demonstrated that the aqueous decoction of Ceiba pentandra leaves has antipyretic properties. The Syrup of dried extracts has retained its febrifuge property. The low toxicity and edibility of the plant represent a safety of use; Ceiba pentandra could be used for the development of antipyretic herbal drug of simple formulation, with pharmaceutical quality, effective and safe to use.

\author{
Funding: No funding sources \\ Conflict of interest: None declared \\ Ethical approval: The study was approved by the \\ Institutional Ethics Committee
}




\section{REFERENCES}

1. Posfay-Barbe K, Hofer M. Fever throughout the ages in children. Revu Medic Suis. 2018;14(594):358-61.

2. Blatteis CM. Fever as a host defense mechanism. Neuro Immune Biol. 2010;9:213-35.

3. Roth J, Blatteis CM. Mechanism of fever production and lysis: lessons from experimental LPS fever. Compr Physiol. 2014;4:1563-604.

4. Issartel B, Peyramond D. Fièvre aiguë chez l'enfant et chez l'adulte: Critères de gravité d'un syndrome infectieux 2e partie: Chez l'adulte. La Revue du praticien (Paris). 2004;54(18):2055-8.

5. Cipolat L, Loeb O, Latarche C, Pape E, Gillet P, Petitpain N. Le paracétamol: connaissance, usage et risque de surdosage en patientèle urbaine de médecine générale. Étude prospective descriptive transversale. Therapies. 2017;72(4):453-63.

6. Elumalai A, Mathangi N, Didala A, Kasarla R, Venkatesh Y. A Review on Ceiba pentandra and its medicinal features. As J Pharm Technol. 2012;2(3):83-6.

7. Friday ET, James O, Olusegun O, Gabriel A. Investigations on the nutritional and medicinal potentials of Ceiba pentandra leaf: A common vegetable in Nigeria. Int $\mathrm{J}$ Plant Physiol Biochem. 2011;3(6):95-101.

8. Laurent Aké-Assi. Quelques plantes alimentaires de cueillette de l'Afrique de l'ouest leur sauvegarde et leur valorisation. Abidjan: NEI-CEDA. 2014:85

9. Enechi DC, Ugwu KK, Ugwu OP, Omeh YS. Evaluation of the antinutrient levels of Ceiba pentandra leaves. Int J Res Rev Pharm Appl Sci. 2013;3(3):394-400.

10. Sarkiyayi S, Ibrahim S, Abubakar MS. Toxicological studies of Ceïba pentandra Linn. Afric J Biochem Res. 2009;3(7):279-81.

11. Muhammad HL, Kabiru AY, Busari MB, Mann A, Abdullah AS, Usman AT, et al. Acute oral toxicity study of ethanol extract of Ceiba pentandra leaves as a glucose-lowering agent in diabetic rats. J Acu Dise. 2016;5:237-43.

12. Saptarini NM, Deswati DA. The Antipyretic Activity of Leaves Extract of Ceiba pentandra Better than Gossypium arboreum. J Appl Pharmaceut Sci. 2015;5 (07):118-21.

13. N'Guessan K, Kadja B, Zirihi G, Traoré D, Aké-Assi L. Screening phytochimique de quelques plantes médicinales ivoiriennes utilisées en pays Krobou (Agboville, Côte -d'Ivoire). Sci Nat.2009;6(1).
14. Lamien CE, Guissou IP, Nacoulma OG. Antiinflammatory, analgesic and antipyretic activities of Dicliptera verticillata. Int J Pharmacol. 2006;2:435-8.

15. Narayana DBA, Stability studies of ayurvedic formulations. Pharm Tim. 2005;37(6):45-50.

16. Ribeiro RV, Silva RMD, Lima JCDS, Martins DTDO. Antiinflammatory, antinociceptive and antipyretic effects of hydroethanolic extract from Macrosiphonia velame (A. St.-Hil.) M. Arg. in animal models. Braz J Pharmaceut Sci. 2010;46(3):515-23.

17. Begum S, Saxena B, Goyal M, Ranjan R, Joshi VB, Rao CV et al. Study of anti-inflammatory, analgesic and antipyretic activities of seeds of Hyoscyamus niger and isolation of a new coumarinolignan. Fitoterapia. 2010;81(3):178-84

18. Adesokan AA, Yakubu MT, Owoyele BV, Akanji MA, Soladoye AO, Lawal OK. Effect of administration of aqueous and ethanolic extracts of Enantia chlorantha stem bark on brewer's yeastinduced pyresis in rats. Afr $\mathrm{J}$ Biochem Res. 2008;2(7):165-9.

19. Taïwe GS, Bum EN, Talla E, Dimo T, Weiss N, Sidiki N, Dawe A, et al. Antipyretic and antinociceptive effects of Nauclea latifolia root decoction and possible mechanisms of action. Pharmaceut Biol. 2011;49(1):15-25.

20. John AA, Christian AA, Philip FB. Development and evaluation of liquidoral phytoformulation of Phyllanthus amarus. J Pharm Res. 2013;6:908-12.

21. Swain PK, Nayak DP. Development and evaluation of poly herbal syrup from some herbs used as expectorant. Wor J Pharm Pharmaceut Sci. 2013;2(5):3848-53

22. Allègre Jade. Les silicates d'alumine (argiles) en thérapeutique. [Thèse de medecine]. [Paris]: Université paris XIII; 2012:134.

23. Le HIR A, Chaumeil JC, Brossard D. Pharmacie galénique: bonnes pratiques de fabrication des médicaments, 10e éd. Elsevier Masson, 2016:382.

Cite this article as: Silue ANG, Djadji LTA, Kouakou LS, Siransy-Kouakou GN. Preclinical research and development of a herbal antipyretic drug based on leaves of Ceiba pentandra (Malvaceae). Int J Basic Clin Pharmacol 2020;9:1778-83. 